\title{
La foto-etnografia como metodologia de investigación para el estudio de manifestaciones conmemorativas contestatarias en el espacio público ${ }^{1}$
}

\author{
Pablo Hermansen Ulibarri ${ }^{2}$ \\ Pontificia Universidad Católica de Chile, Chile \\ phermans@uc.cl \\ Roberto Fernández Droguett ${ }^{3}$ \\ Universidad de Chile, Chile \\ rfd2003@gmail.com \\ Recibido: 6 de agosto de 2017 \\ Aceptado: 15 de mayo de 2018 \\ Disponible en linea: 28 de diciembre de 2018
}

\footnotetext{
1 Este artículo de investigación se basa en fotoetnografías desarrolladas por los autores entre los años 2014 y 2017, en el marco de una línea de investigación sobre etnografía e imagen fotográfica iniciada en el año 2009, con el apoyo del Programa de Psicología Social de la Memoria de la Universidad de Chile y la Escuela de Diseño de la Pontificia Universidad Católica de Chile.

2 Doctor en Arquitectura y Estudios Urbanos, Pontificia Universidad Católica de Chile. Académico, Escuela de Diseño, Pontificia Universidad Católica de Chile.

3 Doctor en Arquitectura y Estudios Urbanos, Pontificia Universidad Católica de Chile. Académico, Departamento de Psicología, Universidad de Chile.
} 


\title{
La foto-etnografia como metodologia de investigación para el estudio de manifestaciones conmemorativas contestatarias en el espacio público
}

\section{Resumen}

En el marco de diferentes investigaciones que hemos desarrollado sobre manifestaciones políticas conmemorativas en el espacio público de Santiago de Chile, en este artículo presentamos la aproximación metodológica fotoetnográfica que elaboramos para observar y comprender el fenómeno desde la perspectiva de las formas de aparición en el espacio público y las luchas por la visibilización de los manifestantes. Asumimos que ni las imágenes ni los modos de narración de los fenómenos sociales en la etnografía son neutros, sino que dependen de la posición de los investigadores, por lo cual nos ubicamos en una perspectiva de diálogo y de cercanía con las luchas de los actores sociales que se manifiestan en estas conmemoraciones. En términos metodológicos, la propuesta que hemos venido desarrollando pretende ofrecer orientaciones epistemológicas y procedimentales sobre la fotoetnografia y la articulación entre saberes y prácticas propias de la etnografia.

Palabras clave: etnografia; fotografia; manifestación política; espacio público

\section{Photo-ethnography as a research methodology for the study of commemorative protests in public space}

\begin{abstract}
In the context of previous research work that we have developed on commemorative political manifestations in the public space of Santiago de Chile, this article seeks to offer a photo-ethnographic methodological approach for observing and understanding this phenomenon from the perspective of the forms of appearance in the public space and the struggles for the visibility of the protesters. We assume that both the images and the modes of narration of social phenomena in ethnography are not neutral, but depend on the positions of the researchers, which is why we place ourselves in a perspective of dialogue and closeness to the struggles of the social actors who manifest themselves in these commemorations. In methodological terms, the proposal that we have been developing aims to offer epistemological and procedural guidelines on photo ethnography and the articulation between knowledge and practices of ethnography.
\end{abstract}

Keywords: ethnography; photography; political manifestation; public space

\section{A foto-etnografia como metodologia de pesquisa para o estudo de manifestações comemorativas contestatárias no espaço público}

\section{Resumo}

No contexto de diferentes pesquisas que já desenvolvemos sobre manifestações políticas comemorativas em espaços públicos de Santiago do Chile, no presente artigo apresentamos a aproximação metodológica foto-etnográfica que elaboramos para observar e compreender o fenómeno desde a perspectiva das formas de aparição no espaço público e as lutas pela visibilização dos manifestantes. Assumimos que tanto as imagens quanto os modos de narração dos fenómenos sociais na etnografia não são neutros senão dependem da posição dos pesquisadores, pelo qual colocamo-nos em una perspectiva de diálogo e proximidade com as lutas dos atores sociais que manifestam nessas comemorações. Em termos metodológicos, a proposta que temos desenvolvido visa fornecer diretrizes epistemológicas e procedimentais sobre a fotoetnografia e a articulação entre saberes e práticas próprias da etnografia.

Palavras chave: etnografia; fotografia; manifestação política; espaço público 


\section{Introducción}

Históricamente, las calles, plazas y parques de las ciudades han sido espacios ciudadanos de manifestación política. Desde el año 2011, las masivas movilizaciones que se desarrollaron en diferentes partes del mundo volvieron a poner en la escena pública no solamente el descontento social y la lucha por una democratización de las sociedades contemporáneas, sino también el carácter político y ciudadano del espacio público (Castells, 2012; Fernández, 2013; Butler, 2017). Uno de los elementos constitutivos de toda manifestación política en el espacio público es su dimensión visual. En tanto espacio de aparición donde los sujetos se encuentran para conversar y actuar juntos en relación a los asuntos de la polis (Arendt, 2005; Butler, 2017), los sujetos que se manifiestan ocupan el espacio público para ser vistos a través de acciones que les permiten visibilizar sus cuerpos, sus consignas y sus reivindicaciones. Como vemos en la figura 1 , los manifestantes no aparecen de cualquier forma ni hacen cualquier cosa. Sus conductas están regidas por pautas y simbolismos inscritos en ritualidades propias de cada manifestación (F. Cruces, 1998; Delgado, 2007). "Las formas canónicas y ritualizadas de la protesta permitirian imprimir un orden a tales eventos a través de una suerte de partitura subyacente que coordina, con un cierto sistema, los gestos, discursos y acciones de los actores" (F. Cruces, 1998, p. 28).

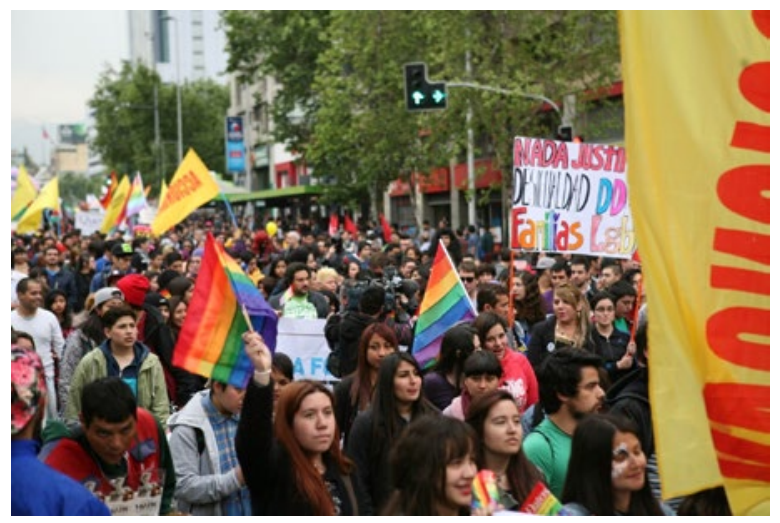

Figura 1. Columna principal de la Marcha por el Orgullo Gay de octubre de 2014, a pocas cuadras de llegar frente al Palacio de La Moneda, sede del Gobierno y corazón del centro cívico de la capital. Esta parada es considerada por muchos de los manifestantes como el momento más significativo de la marcha Fuente: producción propia. 
Desde esta perspectiva, la visibilidad aparece como un elemento fundamental de la manifestación política, ya que esta supone necesariamente poder ser visto (Voirol, 2005; Fernández y Hermansen, 2009; Tassin, 2013), y ser visto es la base para ser reconocido como sujeto ciudadano, perteneciente a una determinada comunidad política (F. Cruces, 1998). Diversos autores comparten la idea de que la constitución del ciudadano entendido como sujeto miembro de una comunidad política, cuya pertenencia le otorga determinados derechos, no se hace efectiva sino en la medida en que el sujeto se constituye como ciudadano a través de sus propias acciones, las cuales, por cierto, contemplan como elemento fundamental la manifestación política (F. Cruces, 1998; Voirol, 2005; Delgado, 2007; Tassin, 2013). Como señala Tassin (2013, p. 10):

en tanto actor político, el ciudadano nace de y por sus acciones, ningún otro título, en teoría, es requerido para ser ciudadano que el de actor, es decir ningún otro título que el hecho de actuar politicamente, comprometerse y exponerse en la escena pública mediante acciones concernientes a los asuntos de la polis. La ciudadanía no es un estatus definido por derechos: es una forma de existir en un modo público y activo. Y es ese modo de acción el que confiere derechos en la medida que los hace aparecer públicamente.

Para Voirol (2005), la lucha por la visibilidad puede entenderse como una dimensión de la acción colectiva que, partiendo de una situación de invisibilidad o de depreciación simbólica, despliega procedimientos prácticos, técnicos y comunicacionales para manifestarse en una escena pública y generar un reconocimiento de prácticas y orientaciones políticas. Desde esta perspectiva, el autor considera que la mayor parte de los movimientos de acción colectiva contemporáneos demandan reivindicaciones de visibilidad, así como el derecho a la existencia social y pública. "La lucha para hacerse oír o hacerse ver no se considera como un aspecto periférico sino por lo contrario central de los levantamientos políticos y sociales contemporáneos" (Voirol, 2005, p. 108). 
La visibilidad a la que nos hemos referido adquiere una nueva relevancia en el contexto actual, donde la digitalización de la imagen y las redes sociales permiten un copioso registro y circulación de imágenes, más aún cuando su difusión muchas veces ocurre casi que en tiempo real (Hermansen y Chilet, 2010). Como señala Butler (2017, p. 95): "las escenas de la calle se vuelven politicamente potentes solo cuando contamos con una versión visual y sonora que se transmita en directo o apenas unos minutos después, de manera que los medios no solo informan del suceso, sino que se convierten en parte de la escena y de la propia acción". Si bien no es objetivo del presente trabajo abordar el rol que juegan los medios de comunicación en las manifestaciones políticas, nuestra experiencia investigativa nos indica que tienen un papel fundamental, no solamente por la difusión de los acontecimientos, sino porque muchas de las prácticas de los manifestantes se desarrollan en función justamente de la cobertura y difusión que estos hacen. "Lo que los cuerpos hacen cuando se manifiestan en las calles está vinculado de una manera esencial con los dispositivos comunicativos y tecnológicos de que hacen uso cuando informan acerca de lo que está sucediendo en la calle" (Butler, 2017 , p. 97). Sin embargo, como podemos observar en la siguiente fotografia obtenida en una manifestación del Orgullo Gay en Chile, la producción de imágenes no es propia ni exclusiva de los medios de comunicación, ya que es cada vez más frecuente que las personas, los movimientos sociales y la ciudadanía en general generen y difundan sus propias imágenes (Hermansen y Chilet, 2010). De este modo, las calles, plazas y parques son espacios para manifestarse, pero también espacios para el registro visual de los manifestantes y sus prácticas, lo cual suele operar bajo la plena conciencia de los actores sociales, quienes tienen cada vez mayor conocimiento de esta dimensión visual y hacen usos estratégicos de ella. Desde esta perspectiva, podemos afirmar que la puesta en escena o performance manifestante pone en juego prácticas de ocupación del espacio público que favorezcan su registro visual en un sentido amplio (fotografias, videos, etc.). Como señala Taylor (2015) a propósito de la participación y cobertura ciudadana de eventos públicos, la fotografia es democrática y todos pueden registrar hechos públicos y hacer circular esos registros, particularmente cuando los medios de comunicación hegemónicos no 
cumplen esta labor. Por lo tanto, la puesta en escena performativa de los cuerpos que se manifiestan supone una visualidad susceptible de ser registrada y difundida, a fin de transmitir mensajes, pero también de generar afectos e interpelaciones (Taylor, 2015).
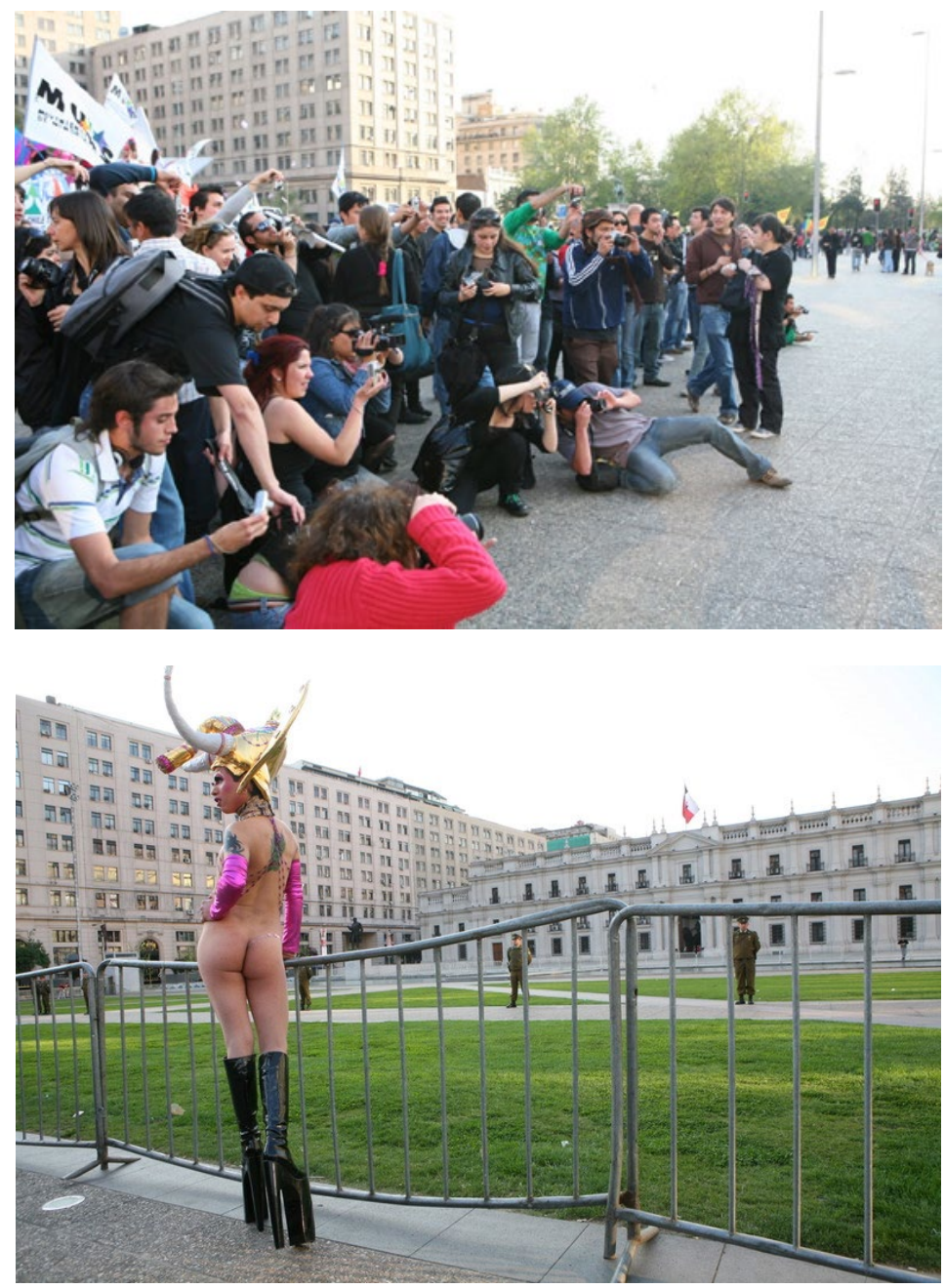

Figuras 2 y 3. Un manifestante de la Marcha del Orgullo Gay (octubre de 2014), usando el Palacio de La Moneda como escena, posa para las cámaras de otros manifestantes y de representantes de medios de comunicación. La posición de su cuerpo expresa una sensualidad no heterosexual, que entra en tensión tanto con la rigidez neoclásica del estilo arquitectónico de la sede de gobierno como con la verticalidad marcial del cuerpo policial de vigilancia

Fuente: producción propia. 
En función de lo anterior es que, basados en nuestra experiencia investigativa en manifestaciones políticas, nos hemos propuesto exponer en el presente trabajo algunos de los fundamentos y procedimientos fotoetnográficos y sus usos en este tipo de manifestaciones. Nuestro objetivo no es solamente contribuir a perfeccionar los procedimientos científico-disciplinarios de registro y análisis, sino también dialogar con el fenómeno de la manifestación política en el espacio público desde una mirada ético-política. Como se ha discutido en diversas tradiciones de las ciencias sociales y particularmente de la etnografia, la investigación no es un conjunto de procedimientos neutros, sino que supone la implicación de los investigadores, más allá de la empatía y la distancia con el objeto de estudio prescrita por las aproximaciones más tradicionales del método etnográfico (Jaramillo Marín y Vera Lugo, 2013). En este sentido nos posicionamos en una perspectiva reflexiva de diálogo crítico con las posiciones políticas que se expresan en las manifestaciones políticas bajo una mirada democrática, cuestionadora y transformadora de un orden social marcado por las desigualdades, las injusticas y la postergación social y política de los sectores subalternos.

Nuestra propuesta metodológica se inscribe en una perspectiva amplia y abierta de la etnografia que dialoga con la sociología visual y otras disciplinas afines que contribuyen a la reflexión sobre las imágenes y sus usos en ciencias sociales (Fernández y Hermansen, 2009; Hermansen y Fernández, 2016). En términos etnográficos, los trabajos de Delgado (2007) y Cruces (1998) en relación con el estudio de fenómenos urbanos y manifestaciones políticas en el espacio público nos han brindado orientaciones fundamentales sobre cómo aproximarnos a las manifestaciones y su dimensión visual. Asimismo, compartimos los planteamientos de Jaramillo Marin y Vera Lugo (2013) respecto de considerar a la etnografia como una forma de producción de conocimientos y saberes situados, que de manera plural adquiere un perfil particular en su desarrollo en lo que los autores llaman el "Sur global". En sus palabras sobre la etnografia, "estamos asumiendo que es una manera particular de observar con sentido, condensar situaciones y acciones sociales de manera rigurosa y sistemática, recuperar experiencias situadas, 
potenciar teóricamente lecturas sobre las mismas, intervenir realidades con propósitos variados y elaborar procesos reflexivos sobre lo desarrollado" (Jaramillo Marín y Vera Lugo, 2013, p. 20).

En este artículo presentaremos y discutiremos algunos aspectos de nuestro trabajo fotoetnográfico en manifestaciones políticas en el espacio público, específicamente en manifestaciones conmemorativas en el centro cívico de Santiago de Chile. Las manifestaciones conmemorativas son manifestaciones que se caracterizan por desarrollarse año a año en alguna fecha significativa y constituirse en un referente simbólico de los movimientos sociales que se identifican y participan de dicha conmemoración (Delgado, 2007; Fernández, 2017). En este caso presentaremos imágenes obtenidas en diferentes años en la marcha del Orgullo Gay y en la marcha contra-conmemorativa de la conquista europea de América.

\section{El lugar de la fotografia en la etnografia}

Desde hace casi ya dos siglos, se usan fotografias para investigar las culturas, y desde hace más de un siglo, Franz Boas y otros pioneros de la antropología moderna naturalizaron el uso de cámaras para el trabajo de campo. Como señala Pink (2006), la etnografia se ha caracterizado por una aproximación que presta especial atención a la cultura material y visual de los contextos sociales que investiga, lo cual, en el marco de las perspectivas contemporáneas de la etnografia, supone asumir que el dato visual, al igual que cualquier otro dato, no es una representación objetiva de la realidad sino más bien una mirada situada sobre esta, que permite elaborar conocimientos pertinentes sobre las prácticas y significados propios de un determinado campo social. Sin embargo, a pesar de la relación bicentenaria entre fotografia y etnografia, y que desde hace ya más de tres décadas la producción, edición y publicación de datos visuales digitales se expande y multiplica, la palabra escrita sigue hegemonizando las lógicas de producción, evaluación y los medios de publicación en las ciencias sociales, quedando la indagación visual, 
en general, y la fotográfica, en particular, relegadas a un lugar secundario, tanto en términos disciplinares como metodológicos y epistemológicos (Hernández, 2006; Fernández y Hermansen, 2009; Hermansen, 2013; Hermansen y Fernández, 2016). Para Hernández (2006), quienes investigan usando datos visuales han estado rodeados por una bruma metodológica y epistemológica, ya que "no hay un consenso en la forma de asumir los datos y en el uso de los mismos" (Hernández, 2006, p. 201). Desde esta perspectiva, en el presente trabajo nos proponemos esbozar una propuesta metodológica sustentada en la etnografía visual que permita describir exhaustivamente y analizar críticamente manifestaciones politicas en el espacio público.

\section{El dato visual en la tradición de la investigación social}

¿Cuáles son las cualidades que, por casi dos siglos, han hecho atractivo al dato visual para un espectro variopinto de investigadores? Los antropólogos positivistas decimonónicos consideraron la fotografia como una toma de muestra de la realidad, un dato primario, producto de la técnica, que prometía convertirse en "una de las adquisiciones más preciadas para el progreso de la ciencia del hombre, [dado que] ya no será indispensable emprender largos viajes para ir a la búsqueda de tipos humanos" (Serres, 1845, p. 29). Profundizando en esta epistemología, Peirce explica dicho interés en el dato fotográfico por su particular calidad indicial, ya que una foto es el "resultado [visible del impacto] de ciertas radiaciones procedentes del objeto [en una superficie fotosensible, que] hacen de ella un índice de alto grado de información” (Peirce, 1986, p. 38).

A pesar del vínculo físico entre la imagen fotográfica y el fenómeno retratado, el dato fotoetnográfico no cumplió con las expectativas levantadas por algunos científicos positivistas que, como Serres, creyeron que un corpus fotográfico sería para los antropólogos de escritorio un sucedáneo exitoso de los datos capturados durante el trabajo antropométrico de campo. A su vez, el creciente escepticismo hacia el positivismo favorece la emergencia 
de una nueva compresión de la fotografia. Durante el último tercio del siglo XX, fuertemente inspirados por los trabajos de Walter Benjamin (1972, 2008), intelectuales como Susan Sontag (2001), John Berger (2009) y Roland Barthes (1981) centran su atención en la experiencia del sujeto que observa la imagen fotográfica. Dicho de otra forma, la particular indicialidad que proviene del proceso de producción de una fotografía cede el protagonismo a la reflexión respecto al comportamiento "deíctico" de la imagen fotográfica mientras es leída. Es decir, cómo interpela al observador más allá de su cualidad formal y su contenido (Barthes, 1981; Sontag, 2001; Green, 2003; Berger y Mohr, 2009). Quienes se aproximan al dato fotográfico desde la deixis, consideran sus significados como subjetivos, principalmente: dependen de quién observa, dónde lo hace, en qué momento $\mathrm{y}$, finalmente, de las memorias que gatilla. Para Roland Barthes (1981) hay un espacio infranqueable entre el fenómeno fotografiado y el sujeto que observa la imagen fotográfica. Llama punctum (Barthes, 1981) al momento en que una parte de la fotografia punza la memoria de quien la observa, desplazando a un segundo plano -o haciendo desaparecer- el vínculo indicial entre la fotografia y lo fotografiado. Dicho por John Berger, esta experiencia es el momento en que "su ambigüedad por fin deviene verdadera” (Berger y Mohr, 2009, p. 288; cursivas en el original). Para quienes se centran en la deixis como cualidad definitoria del dato fotoetnográfico, su uso en investigación se ha desarrollado principalmente en la elicitación de significados desde los sujetos indagados (Collier, 1957) y en la amplificación de su voz durante la investigación, para así horizontalizar la relación entre investigadores y los sujetos indagados (Warren, 2005).

\section{Articulación entre índice y deixis como principio activo}

Dado que consideramos como cualidades constitutivas del dato fotoetnográfico, tanto al vínculo físico entre lo fotografiado y la imagen fotográfica, como a la potencia de una fotografia de ser una fuente inagotable de significados, nos proponemos articular estas dos dimensiones. Mediante esta articulación buscamos armonizar 
indicialidad y deixis, es decir, convertir la tensión entre estas dos cualidades inherentes del dato fotoetnográfico en motor metodológico. Siguiendo a Tim Ingold $(2016,2017)$, quien recupera el sentido griego original del término, comprendemos armonizar como la construcción de un balance activo que resulta de la atención reciproca entre dos fuerzas divergentes y constitutivas de un asunto. Por un lado, en cuanto índices, nuestros datos fotoetnográficos apuntan hacia fenómenos sociales de los que fuimos parte, describiéndolos con un "bajo grado de abstracción" (Collier y Collier, 1986, p. 7). Por otro, aparte de recuperar la memoria de los hechos que retratan, la deixis de nuestros datos fotoetnográficos gatilla asociaciones con un espectro amplio de conocimientos y saberes. La interacción entre estas fuerzas, divergentes y complementarias, activa la construcción de "conocimiento situado" (Haraway, 1995). Interpelando la estrategia de dominación masculina que presenta su saber como universal, Haraway levanta "una doctrina de la objetividad encarnada que acomode proyectos de ciencia feminista paradójicos y críticos: la objetividad feminista significa, sencillamente, conocimientos situados" (Haraway, 1995, p. 324; cursivas en el original). Este conocimiento situado, consonante con las teorías no representacionales, nos impulsa a trabajar los datos fotoetnográficos como "bloques de sensaciones con intensidad afectiva: tienen sentido no sólo porque invertimos tiempo para averiguar lo que significan, sino también porque su materialidad afectiva pre-significante se siente en el cuerpo" (Latham y McCormack, 2009, p. 253). La consideración de Latham y McCormack se corresponde con la tensión entre indicialidad y deixis y aporta un segundo principio activo, a saber, la tensión entre afectividad y capacidad descriptiva.

En la relación entre indicialidad y deixis, la tensión entre afectividad y capacidad descriptiva se plasma en una "narrativa fotográfica” (Berger y Mohr, 2009, p. 287), en la cual se analizan e interpretan los datos fotoetnográficos. En contraste con la imagen en movimiento -cine, video, televisión, etc.-, que impone al espectador una trama y el ritmo con que esta se hace disponible, en la narrativa fotográfica es el observador quien asume un rol activo, poniendo en movimiento la narración, definiendo en cada instante 
su orden, sentido y ritmo (Berger y Mohr, 2009). Consistentemente, en los conjuntos de datos fotoetnográficos, el flujo narrativo es el proceso de elicitación, análisis e interpretación. Sin embargo, respecto a la narrativa fotográfica como la concibe Berger, la presente propuesta metodológica incorpora la reflexividad, ya que somos los mismos investigadores los que, por un lado, producimos los datos fotoetnográficos y, por otro, desarrollamos su análisis e interpretación. De esta manera, nos proponemos imbricar las dimensiones ético-política y metodológica-disciplinar de la indagación, mediante la "correspondencia" (Ingold, 2016, 2017) entre la investigación fotoetnográfica y los modos y fines de la manifestación política. Si concordamos en que quienes se manifiestan lo hacen para ser vistos, registrados y publicados reivindicando sus prácticas e idearios, al registrar fotográficamente las manifestaciones nos hacemos parte activa de la operación performativa de quienes se manifiestan: fotoetnografía y manifestación ocurren en mutua "correspondencia" (Ingold, 2016, 2017). La correspondencia "es el proceso mediante el cual los seres o las cosas literalmente se van respondiendo mutuamente en el tiempo" (Ingold, 2017, p. 14), por lo cual apuntamos a un entrelazamiento mutuo que sobrepasa las interacciones meramente investigativas. Más que observadores participantes actuando desde la intencionalidad indagativa, nos incorporamos operativa, emocional y simbólicamente en la densa trama de subjetividades que la manifestación pone en juego (Ingold, 2016, 2017).

\section{Producir y analizar fotografias de manifestaciones conmemorativas}

Los resultados que presentaremos a continuación fueron organizados para hacer foco en dos momentos de la indagación fotoetnográfica: producción y análisis. Esta separación en dos momentos no es una separación entre distintos tipos de procedimientos -técnicos, analíticos o creativos-. Al contrario, reconocemos en cada una de estos momentos dimensiones procedimentales, reflexivas e interpretativas. 
De hecho, la producción del presente corpus fotoetnográfico sobre manifestaciones políticas en el centro cívico de Santiago de Chile ha conllevado, por lo general, decisiones que, en lo estrictamente técnico, puede tomar acertadamente cualquier persona con conocimiento fotográfico básico. Las manifestaciones indagadas se desarrollaron en exteriores, mayormente con luz de día, y en contextos que los investigadores conocemos por vivir en la ciudad.

Consecuentemente, el equipamiento fotográfico a utilizar en estos contextos debe combinar un registro de alta calidad y resolución con una adecuada portabilidad y autonomía, en cuanto a la capacidad de la batería y de almacenamiento de imágenes. Respecto a los lentes a utilizar, todos son adecuados. Por un lado, la expresividad de un gran angular de más de $120^{\circ}$ o de un teleobjetivo con menos de $5^{\circ}$ de ángulo de visión favorece la captura de imágenes originales y elocuentes. Por otro, para obtener fotografias que permitan reconocer y describir tanto la configuración general de las escenas retratadas como las relaciones entre actores sociales y los contextos en los que se manifiestan, es altamente recomendable contar con un rango de lentes conocidos como normales, a saber, los que cubren un ángulo de visión entre los $20^{\circ}$ y los $65^{\circ}$. Los lentes fotográficos normales producen imágenes que, en cuanto a perspectiva y profundidad de campo, no se alejan diametralmente del tipo de imágenes que producen nuestros glóbulos oculares. Consecuentemente, los datos fotoetnográficos producidos con lentes normales se acercan a la manera como los sujetos que se manifiestan prevén que serán vistos. Esta decisión técnica favorece que los datos fotoetnográficos se construyan en consistencia con la manera como los sujetos quieren ser vistos. De este modo, buscamos armonizar procedimiento, metodología y epistemología con un compromiso ético y político.

Más aún, operando de esta manera no solo interactuamos con los manifestantes, sino que favorecemos una relación de correspondencia (Ingold, 2016, 2017) con ellos: retratamos en el espacio público a quienes se manifiestan para ser vistos, lo hacemos desde una perspectiva que ellos sugieren performativamente y cuyo resultado pueden, en cierta medida, prever. Cabe precisar que en el trabajo que presentamos en este artículo la labor fotoetnográfica no estuvo acompañada de 
otras formas de indagación, como por ejemplo entrevistas u otras estrategias de producción de datos textuales. Si bien consideramos que la fotoetnografía puede establecer la correspondencia anteriormente señalada, en el sentido de proponer interpretaciones congruentes con las perspectivas de los actores sociales que se manifiestan, también pensamos que el poder acompañar las interpretaciones que se derivan de la fotoetnografia con la palabra de los sujetos permite triangular el fenómeno y reforzar las interpretaciones y su correspondencia, ya que siempre existe la posibilidad de que el investigador anteponga su propia mirada sobre la de los actores sociales.

En la figura 4, correspondiente a la marcha del Orgullo Gay, vemos a un manifestante que se visibiliza mediante una performatividad política no tradicional.

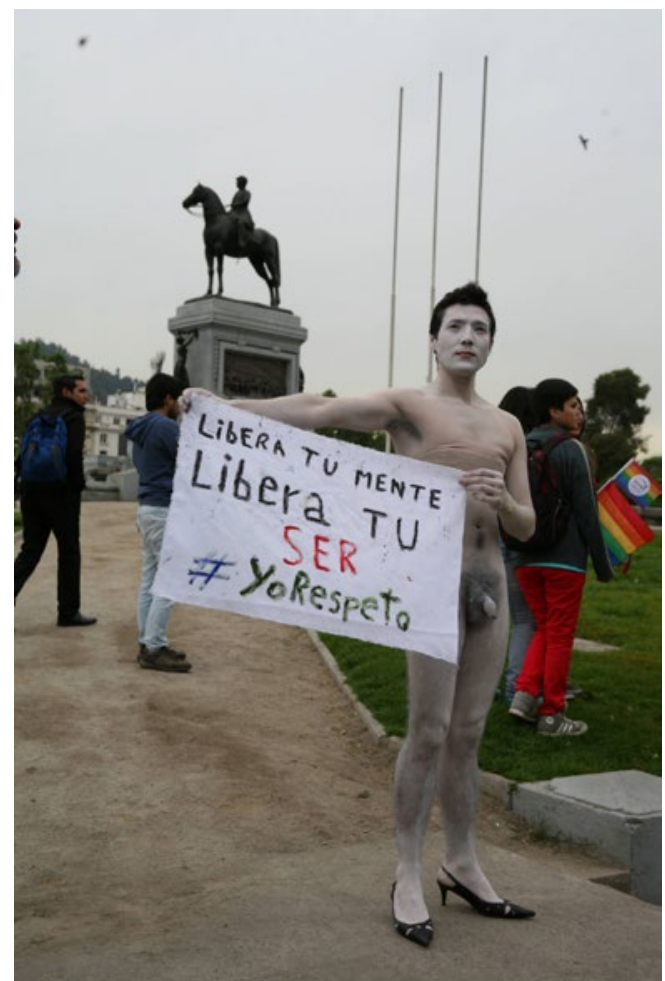

Figura 4. Manifestante, parte de la Marcha del Orgullo Gay del 2014, en plaza Baquedano, antes de marchar hacia el palacio presidencial de La Moneda Fuente: producción propia. 
Materializando nuestra opción por la correspondencia, la figura 4 está tomada considerando las indicaciones performativas que el sujeto evidencia. Primero, la posición adoptada por el fotoetnógrafo retrata lo que creemos es la fachada de la performance, ya que el letrero y la cara del sujeto se presentan de manera frontal. Segundo, dado que la distancia entre el manifestante y el fotoetnógrafo es de aproximadamente cinco metros -libres de objetos que impidan el contacto visual reciproco-, que el retratado estaba alli antes de la llegada del fotoetnógrafo, y que el manifestante permaneció tranquilo en su posición mientras duró la sesión fotográfica, podemos afirmar que el sujeto se presenta para ser retratado. $\mathrm{Al}$ mismo tiempo, el uso de un lente normal (de $70 \mathrm{~mm}, 34^{\circ}$ de ángulo de visión) permitió retratar la performance completamente -de cuerpo entero- $y$, en segundo plano pero reconocible, la estatua que el sujeto eligió como fondo para entrar en diálogo y contraste con ella. La estatua del General Baquedano juega un rol simbólico de doble escala. Primero, el personaje es considerado un prócer de la patria por sus diversos roles militares durante el siglo XIX -los que incluyen su participación en dos guerras contra Perú y Bolivia, el aplacamiento de varios levantamientos armados en la naciente república y la reorganización del ejército-; esto es, sin duda, un baluarte simbólico de la República de Chile. Luego, su estatua está colocada en el punto cero de la ciudad: la numeración de todas las calles de Santiago aumenta a medida que se alejan de él. La estatua del General Baquedano juega como origen simbólico, histórico y geográfico de la capital del Chile burgués y patriarcal. Este trasfondo entra en tensión con el manifestante, que posa semidesnudo, empolvado de blanco, sosteniendo una pancarta y mirando épicamente al horizonte, como una suerte de estatua humana masculina. El diseño de cada una de las partes de su performance entra en un diálogo que interpela la fría institucionalidad que sostiene la memoria de Baquedano y, en la misma operación, se humaniza. Si la estatua de Baquedano contiene frases escritas en bronce que enarbolan la guerra, la patria y el honor, la estatua performada escribe sobre una tela liviana y con orillas sin terminar "LibERA TU MENTE Libera TU SER", con una caligrafia irregular y de terminación descuidada. Dado que el aspecto casual de la caligrafia y su soporte contrastan con el cuidado oficio del maquillaje corporal, podemos especular que el descuido tiene la intención de reforzar el mensaje escrito: para alcanzar la libertad de la mente y del ser, debemos liberarnos de los estereotipos formales 
hegemónicos. A diferencia de los letreros de las estatuas conmemorativas tradicionales, la estatua performada por el manifestante incorpora en su letrero el hashtag "\#YoRespeto", que aumenta digitalmente su performance y la asocia a los flujos de las controversias en las redes sociales. En el contexto de la Marcha del Orgullo Gay -que se explicita en las banderas que portan quienes aparecen entre el manifestante y la estatua de Baquedano-, la tensión que el performista despliega entre lo femenino y lo masculino adquiere sin duda la calidad de declaración política. Por un lado, la feminidad aparece a través del uso de zapatos de tacos altos y de una tela que cubre sus pectorales, que puede hacer referencia tanto al pudor que lleva a muchas mujeres a cubrir sus senos como a la práctica de otras mujeres que se aplastan sus senos para representar una figura masculina. Al mismo tiempo, incorpora lo masculino mediante su cuerpo cubierto de maquillaje marmóreo, la exhibición de sus genitales y la mirada a lontananza del Prócer de la Patria. Finalmente, el sujeto desarrolla otra vinculación con la estatua del General Baquedano: al poner su pancarta en un espacio común, tanto a la estatua de Baquedano como a su propia autorrepresentación de estatua, obtiene una posición en el espacio público que, aunque efimera, invita a cambiar la militarización simbólica de la República, representada por Baquedano, mediante el imperativo "LibERA TU MENTE Libera TU SER".

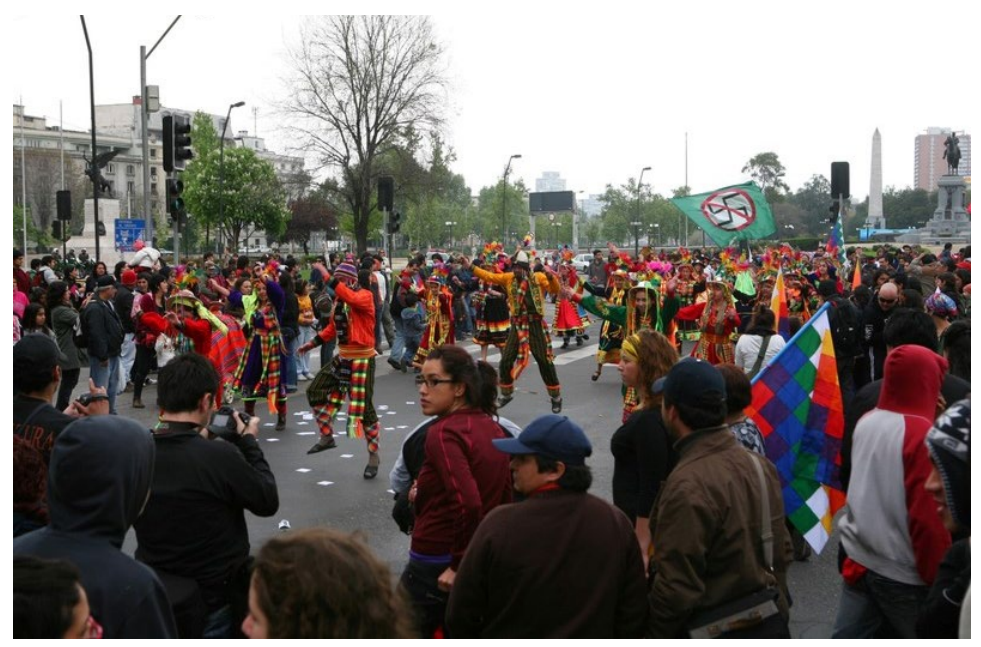

Figura 5. Grupo de Danza Tinku en la marcha del 12 de octubre de 2015, comenzando su recorrido desde Plaza Baquedano hasta el Palacio de La Moneda Fuente: producción propia. 
La fotografia de la figura 5 fue tomada durante la marcha contra-conmemorativa que representantes de pueblos originarios y otros grupos políticos afines realizan por el centro cívico de Santiago de Chile cada 12 de Octubre, para resistir "dignamente el colonialismo opresor del estado chileno y el capitalismo destructivo instaurado en nuestro territorio" (N. Cruces, 2015). En la imagen, vemos a un grupo de aproximadamente 40 bailarines comenzando los 2.7 kilómetros de marcha, durante los cuales bailarán la Danza del Tinku. Inician su performance en la cara poniente de la Plaza Baquedano -punto de partida tanto de esta como de las principales manifestaciones ciudadanas en Santiago- y culminan en la Plaza de Los Héroes. Este recorrido por la principal avenida de la capital presenta una serie de hitos simbólicos de la República de Chile (Plaza General Baquedano, Pontificia Universidad Católica de Chile, Palacio de La Moneda, entre otros), principal rival político o, en el extremo, enemigo de guerra de algunos de los colectivos manifestantes. La Danza del Tinku es un baile ritual andino que se formaliza en el siglo XX como la representación artística del Rito del Tinku, que es un evento preincaico de combate, parte del arte de la guerra de las culturas andinas. Dada su belleza performativa y su raíz preincaica, la danza del Tinku ha sido adaptada, reapropiada y resignificada para desplegarse en contextos urbanos con fines identitarios, políticos y contestatarios (Fernández Droguett y Fernández Droguett, 2015). Este desplazamiento tanto espacial (de lo étnico a lo rural y luego a lo urbano) como funcional (de lo ritual y religioso, con expresiones de violencia física, a lo político, basado en un despliegue artístico-performativo), parecen indicar que la Danza del Tinku, si bien mantiene una dimensión identitaria relativa al mundo andino preincaico, desplegado en el centro cívico de Santiago de Chile, adquiere un carácter postidentitario en la medida que resitúa y resignifica esta práctica. Al resituar la Danza del Tinku como práctica política urbana, estos manifestantes no solo inscriben temporalmente en el centro cívico de la ciudad una multiculturalidad que le diputa la hegemonía al poder político republicano, sino que además resignifican y transforman el mismo centro cívico al ser usado como escena de estas ritualidades ancestrales.

La fotografia fue realizada desde una jardinera de 60 centímetros de alto, localizada en el bandejón central de la Avenida Alameda. Usamos un lente gran angular (de $28 \mathrm{~mm}, 74^{\circ}$ de ángulo de visión) con el objetivo de 
encuadrar tanto al grupo de Tinku como su entorno. Consecuentemente, lo retratado en la figura 5 da cuenta tanto de la escena -simbólicamente híbrida- en la que se desarrolla la Danza del Tinku, como de las relaciones espaciales entre los sujetos que participan en esta danza, sea como bailarines, espectadores o haciendo registro de ella. Lo primero que llama nuestra atención es la relevancia del color como dispositivo de visibilización. En contraste con los tonos grises, cafés, verdes y negros de esta parte de la ciudad, de su vegetación y de las ropas de quienes asisten a la marcha, las ropas de los bailarines y las banderas desplegadas -Wiphala y antifascista- coinciden en un llamativo espectro de colores -blanco, negro, primarios y secundarios- fuertemente saturado. Lo anterior se suma al contraste entre el silencio y la inercia de la calle, semáforos, estatuas y otros equipamientos urbanos, y la vitalidad de quienes usan las vías para el tránsito motorizado para realizar la Danza del Tinku, que impide el uso habitual de esta infraestructura urbana.

Finalmente, nos interesa destacar la presencia de numerosas personas registrando la escena, ya sea con sus propios dispositivos móviles como con cámaras de lentes intercambiables y de video. Más allá de la cobertura de los medios de comunicación, el registro no profesional, realizado tanto por paseantes ocasionales como por manifestantes preparados para ello, proyecta en la memoria y en las redes sociales digitales esta apropiación efimera de la ciudad.

\section{Análisis secuencial de fotografias}

Como podemos ver en los ejemplos anteriores, las fotografias permiten identificar y analizar elementos visuales relevantes de las prácticas de los manifestantes. Sin embargo, además del uso de fotografia una a una, nuestra propuesta fotoetnográfica también permite analizar varias fotografias al mismo tiempo, lo que permite ampliar y profundizar los resultados del análisis de cada fotografia por separado. Como sostiene Rieger (1986, p. 7), "una sola fotografia, por sí misma, puede tener muchos significados diferentes. Cuando otra foto es puesta a su lado, el significado de la primera es desafiado y precisado. Mientras 
más fotos, mayor es el grado de precisión en la interpretación a hacer respecto de cualquiera del grupo".

En la siguiente secuencia fotográfica vemos cómo coexisten diferentes expresiones de visibilización en el espacio público durante las manifestaciones, que tienen en común el uso del cuerpo como soporte de reivindicaciones, o como nos dijo un informante clave participante de estas manifestaciones, el uso del cuerpo "como lienzo".

En las figuras 6, 7 y 8 observamos cómo tres tipos distintos de indumentaria funcionan como instrumento para evidenciar situaciones a reivindicar. A diferencia de las frases o palabras que los manifestantes plasman en banderas, pancartas y lienzos, los cuerpos e indumentarias retratados adquieren su sentido reivindicativo en relación con el contexto en el que ocurren. A su vez, dicho contexto también es uno en disputa, ya que, por un lado, las manifestaciones suceden en el centro cívico de Santiago y, por otro, subvierten las prácticas habituales del mencionado espacio urbano. En consecuencia, el "cuerpo como lienzo" se instala como una tercera coordenada que tensiona las dos anteriores -centro cívico y manifestación reivindicativa- para construir su significado.

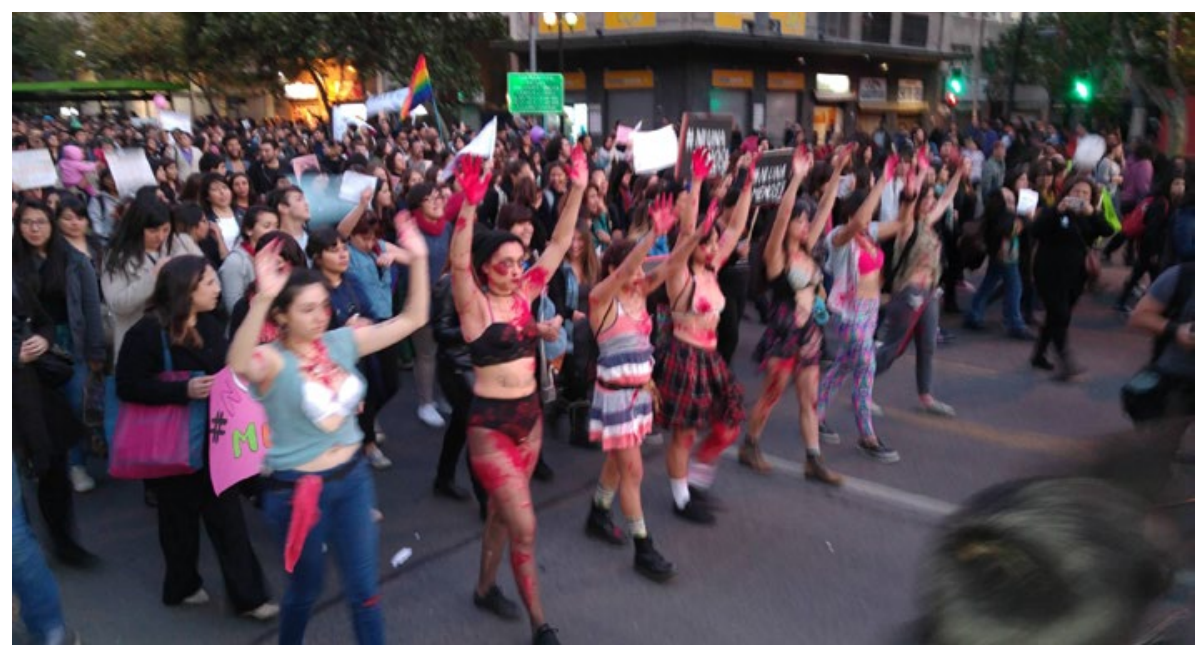

Figura 6. Performance contra el femicidio en la marcha "Ni una menos", realizada en el 2017 por la Avenida Alameda entre la Plaza General Baquedano y la Plaza de Los Héroes, columna del centro cívico de Santiago

Fuente: producción propia. 
Siguiendo lo planteado atrás, la manifestación "Ni una menos" se propone interpelar la capacidad de los instrumentos legales disponibles para proteger a las mujeres de la violencia machista; por su parte, como vemos en la figura 6, siete mujeres manifestantes interpelan la abstracción de la convocatoria general, mediante el uso de ropas rotas y representando sus cuerpos heridos -es decir, las consecuencias físicas inmediatas de las agresiones machistas y femicidas- mientras marchan con sus manos en alto; señal que puede leerse como una acción decidida hacia una resistencia no violenta.

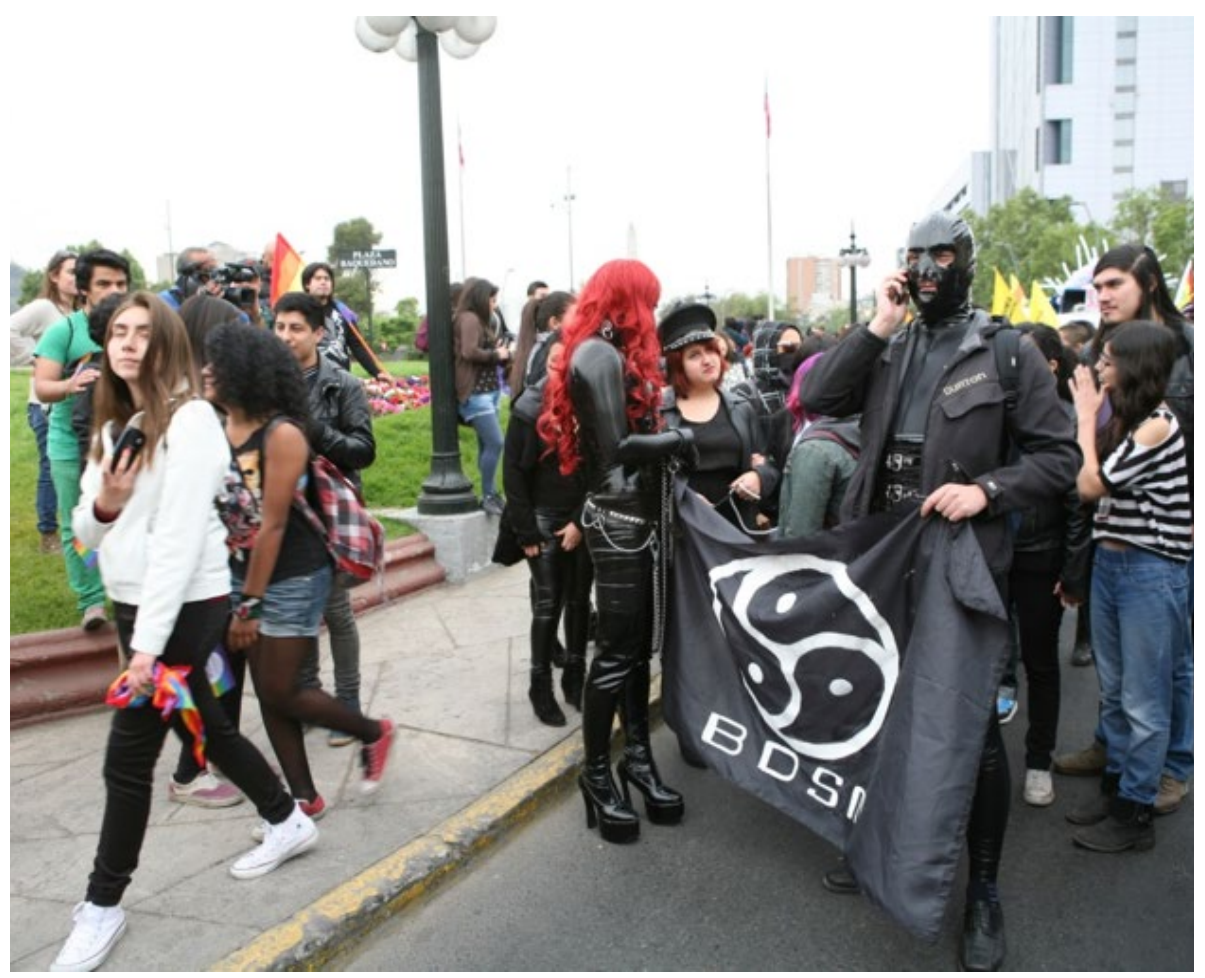

Figura 7. Integrantes de un colectivo BDSM se preparan para participar en la Marcha del Orgullo Gay 2014

Fuente: producción propia. 
En la figura 7, miembros de un colectivo BDSM esperan para iniciar la caminata por la Avenida Alameda -a través del centro cívico- junto con los otros grupos que participaron de la versión 2014 de la Marcha del Orgullo Gay. Como en los otros casos analizados, esta marcha interrumpe el uso cotidiano de esta parte de la ciudad, pero al mismo tiempo estresa las convenciones heterosexuales del poder político. A diferencia de las siete manifestantes de la figura 7 , que componen ropas y maquillajes especialmente diseñados para su performance, los BDSM usan indumentarias propias de su inscripción para manifestarse, que adquieren carácter reivindicativo y de visibilización política fuera de su contexto habitual, esto es, en el espacio público del centro cívico y dentro de la manifestación conmemorativa en la que participan.

Finalmente, en la figura 8 , cuatro miembros de un colectivo trans junto con una manifestante contra la violencia de género posan delante de La Moneda exhibiendo propaganda impresa que reclama por la promulgación de una ley de identidad de género en Chile. En la escena retratada, que ocurre recién finalizada la marcha, vemos cómo el tránsito de vehículos motorizados ha vuelto a poblar la Avenida Alameda. En contraste con las escenas retratadas durante la manifestación, esta imagen nos muestra a los manifestantes en el centro cívico, pero fuera de la manifestación, lo que amplifica la excepcionalidad de sus cuerpos e indumentarias en dicho contexto. De hecho, como dato fotoetnográfico aislado, una primera lectura de esta imagen no evidencia la dimensión política que se proponen los sujetos mediante su estrategia de visivilización: solo en relación a una secuencia de imágenes que evidencie esta escena como un último momento de resistencia performativa a la normalidad es que la pose de las cinco personas fotografiadas recupera su carácter político reivindicativo. 


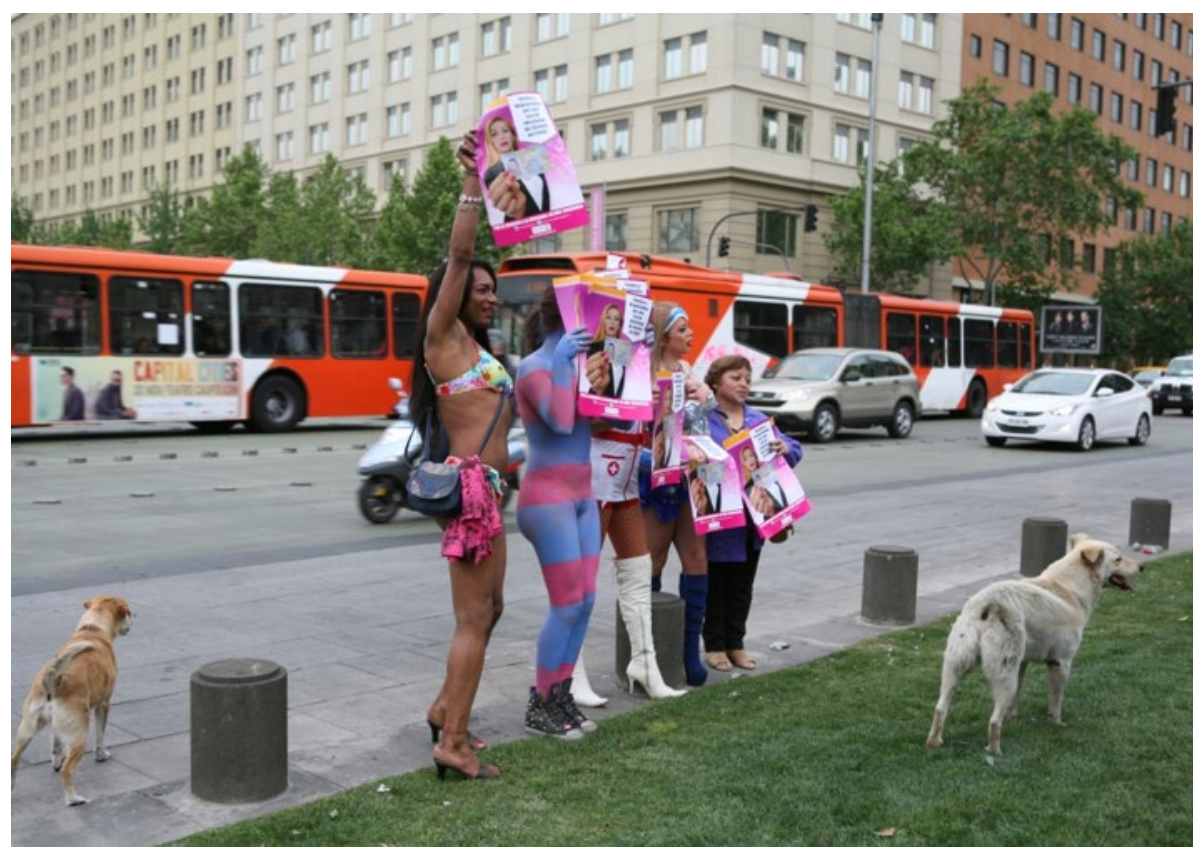

Figura 8. Al final de la jornada de manifestación, cinco sujetos posan para ser retratados delante del Palacio de Gobierno exhibiendo propaganda por el reconocimiento legal de la identidad de género Fuente: producción propia.

En esta otra secuencia, vemos la importancia que sigue teniendo el uso de estrategias expresivas más tradicionales como son las pancartas, banderas y lienzos. En la figura 9, un conjunto de colectivos lesbofeministas se manifiestan, durante la Marcha del Orgullo Gay, en lo que denominaron como La Otra Marcha. Tomando distancia de lo que un informante describió como un modo festivo "cuando no hay nada que celebrar", en directo contraste con la performatividad característica del Parade, La Otra Marcha despliega un modo de manifestación política tradicional: sus cuerpos componen una columna que marcha levantando pancartas con textos. Productiva y formalmente, a excepción del lienzo que está hecho de tela, la factura de las pancartas demuestra consistencia, en cuanto todas son de cartón café y las letras de cada una son de un solo color y están escritas a mano. 


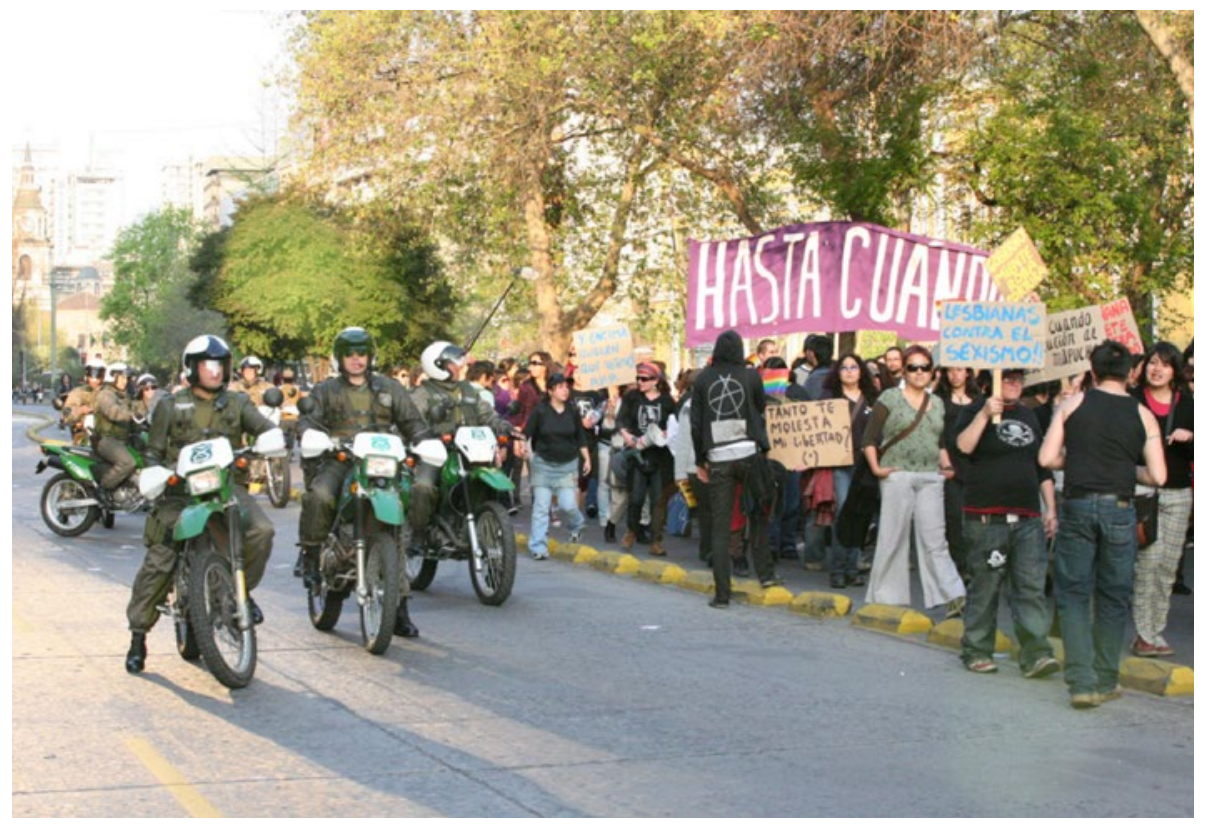

Figura 9. Durante la Marcha del Orgullo Gay, en La Otra Marcha, compuesta por colectivos lesbofeministas, se utiliza una estrategia de manifestación más tradicional, con banderas y lienzos

Fuente: producción propia.

Si bien coinciden en el uso de pancartas y lienzos y en la primacía de los mensajes escritos, como se observa en la figura 9, dentro de la Marcha del Orgullo Gay, los miembros y simpatizantes de la Fundación Iguales visibilizan su agrupación y su ideario mediante banderas, poleras y carteles que, por su consistencia formal, evidencian una estructura orgánica institucional y disponibilidad de recursos para la producción seriada de identificadores visuales.

Por último, un lienzo horizontal -o varios alineados- permite a los manifestantes crear una fachada amplia para hacer visibles sus reivindicaciones. Como se observa en la figura 10, situados en el punto de partida de la Marcha del Orgullo Gay, el colectivo "Cristianxs x la Diversidad", mediante la utilización de tres lienzos de papel con letras pintadas a mano, soportados por once personas, consigue construir una fachada de nueve metros de frente que logra hacer visibles sus postulados a una escala apropiada para el sector de la ciudad en que se manifiestan. 


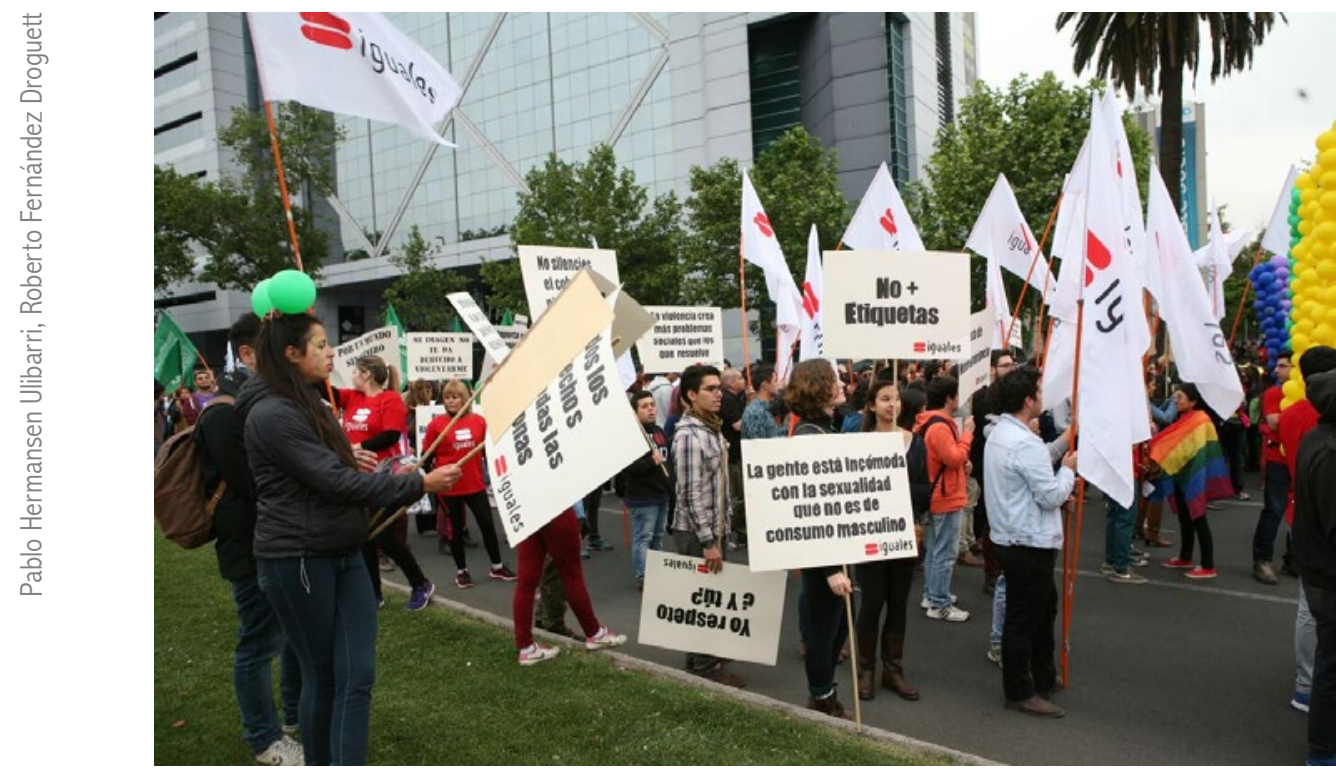

Figura 10. La Fundación Iguales utiliza banderas, poleras y carteles que evidencian su organización institucionalizada Fuente: producción propia.

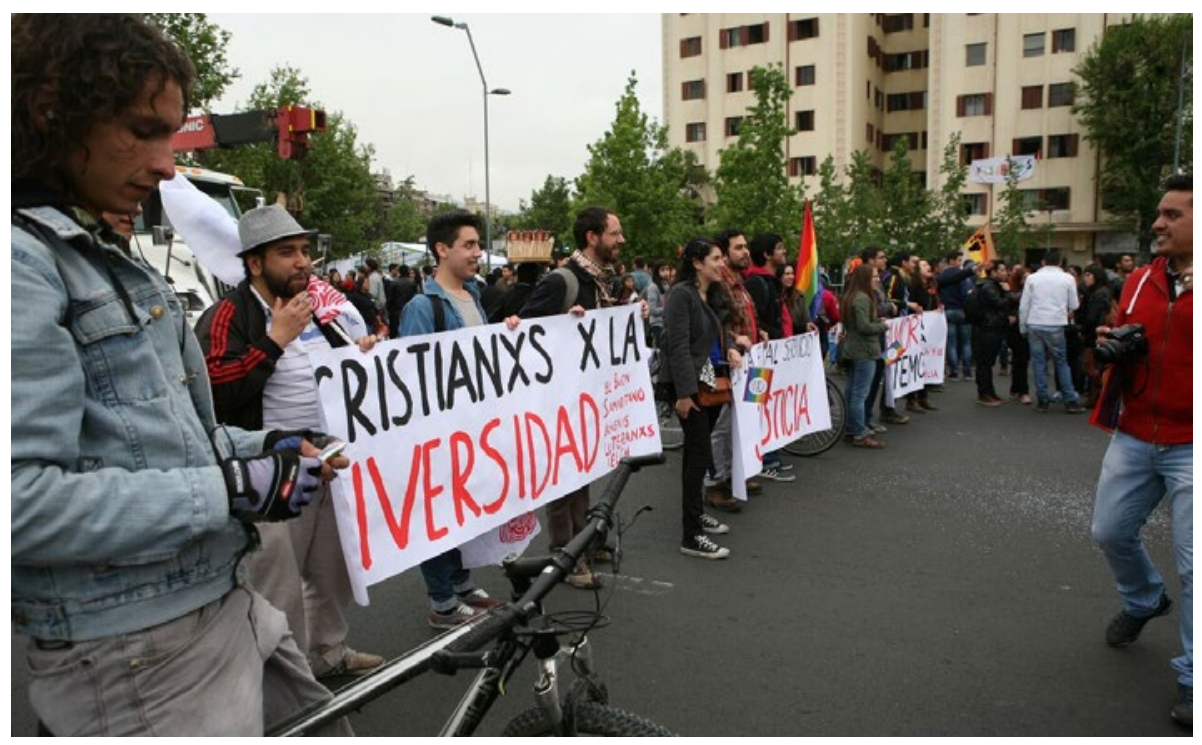

Figura 11. Al inicio de la Marcha del Orgullo Gay, el colectivo "Cristianxs x la Diversidad" despliega lienzos de papel con sus postulados escritos Fuente: producción propia. 
En función de estos ejemplos, vemos que el análisis de conjuntos de fotografias permite abordar la pluralidad de prácticas de visibilización que se desarrollan en manifestaciones politicas, sin reducir las consignas y performances a un conjunto acotado de estas. En términos ético-políticos, el fotoetnógrafo no solamente debe dar cuenta de los elementos más salientes o visibles de las manifestaciones, sino que además debe procurar buscar y registrar la variabilidad de prácticas en aras de dar cuenta de ellas de forma sistemática y rigurosa, en la medida en que dicha variabilidad constituye un rasgo característico de la mayor parte de las manifestaciones políticas contemporáneas. Como señalamos en un comienzo, en el caso de este trabajo no implementamos estrategias complementarias de producción de datos, como entrevistas u otras, por lo que la rigurosidad analítica y la reflexividad en torno a las interpretaciones propuestas deben ser particularmente minuciosas. Ello, con el fin de no reproducir la tendencia a imponer los marcos comprensivos del investigador, y de poner en juego dichos marcos desde una perspectiva dialógica que procure mantener el foco en el sentido estético y político en el que las acciones de los actores sociales se inscriben.

\section{Conclusiones}

En la lectura de Jaramillo y Vera (2013) sobre la etnografia en el Sur global, se hace hincapié en que la producción de conocimiento etnográfico se encuentra situada en contextos de dominación pero también de insubordinación y resistencia, por lo cual los modos de representación de los sujetos y de sus prácticas en estos contextos deben dialogar reflexivamente con las circunstancias y las luchas de estos sujetos. Sin embargo, no desconocemos el dilema planteado por Ruby (1991), quien sostiene que, aunque los investigadores que trabajan con imágenes usen modos de indagación que se propongan dar voz a los que no la tienen mediante la co-creación de conocimiento -incorporando como actores a los sujetos indagados-, de todas formas suelen terminar imponiendo sobre quienes intentan visibilizarse el poder de sus técnicas de registro y de los ámbitos de distribución en los que se inscriben. En este sentido, en nuestra propuesta fotoetnográfica para la investigación de y en manifestaciones 
politicas, hemos querido proponer no solamente algunas sugerencias técnicas de trabajo de campo, sino también las reflexiones ético-politicas que fundamentan dichas operaciones técnicas, basadas mayormente en que tanto la producción de imágenes fotográficas como su análisis se oriente en función de la noción de correspondencia (Ingold, 2016, 2017), es decir, que la labor del fotoetnógrafo esté articulada de modo dialógico y reflexivo con el fenómeno investigado.

Asimismo, el registro y análisis de la dimensión visual de las manifestaciones abre perspectivas de representación en las que los manifestantes aparecen como sujetos del relato etnográfico y como cuerpos puestos en juego en una escena pública en la que se visibiliza en tanto sujeto político. Como señala Butler (2017, p. 17), "la acción conjunta puede ser una forma de poner en cuestión a través del cuerpo aspectos imperfectos y poderosos de la política actual". Como vemos en la figura 12, el despliegue de los cuerpos, con mayor o menor grado de intervención en sus formas de aparecer públicamente, refuerza y materializa/corporaliza las demandas de los manifestantes, y la fotoetnografia permite, de manera más exhaustiva y compleja que la mera escritura etnográfica, dar cuenta de estos modos de aparición.

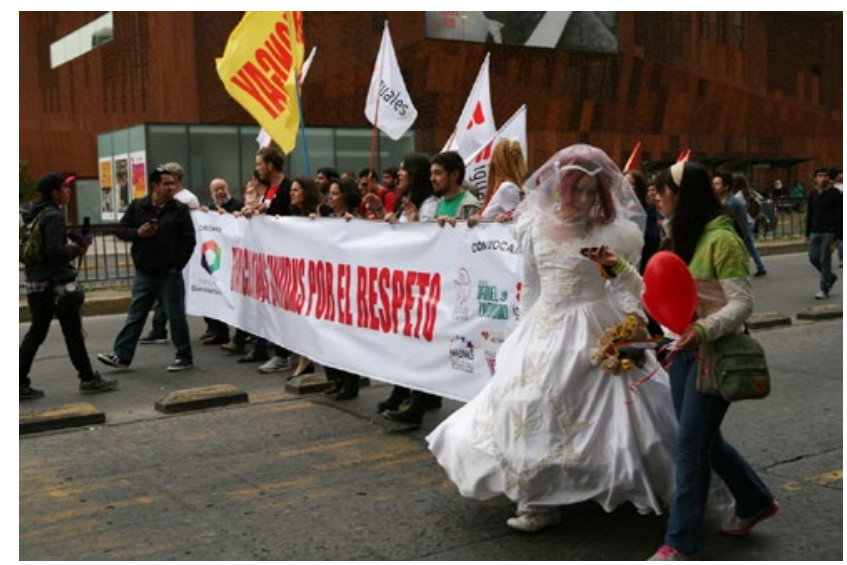

Figura 12. En esta escena de la Marcha del Orgullo Gay conviven varios de los elementos analizados en el presente artículo. Por una parte, se despliegan, mediante banderas y un lienzo, las identidades visuales de diferentes grupos participantes en la marcha. Por otra, un manifestante perteneciente a un colectivo trans usa su cuerpo para visibilizar performativamente la demanda por un matrimonio igualitario Fuente: producción propia. 


\section{Referencias}

Arendt, H. (2005). La condición humana. Buenos Aires: Paidós.

Barthes, R. (1981). Camera lucida. Reflections on Photography (Trans. R. Howard). New York: Hill \& Wang.

Benjamin, W. (1972). A Short History of Photography. Screen, 13(1), 5-26. doi: $10.1093 /$ screen/13.1.5

Benjamin, W. (2008). The Work of Art in the Age of Mechanical Reproduction. Londres: Penguin Books Limited.

Berger, J. y Mohr, J. (2009). Otra manera de contar. Barcelona: Gustavo Gili.

Butler, J. (2016). Frames of War: When Is Life Grievable? Nueva York: Verso Books.

Butler, J. (2017). Cuerpos aliados y lucha politica: Hacia una teoria performativa de la asamblea. Buenos Aires: Paidós.

Castells, M. (2012). Redes de indignación y esperanza: los movimientos sociales en la era de internet. Madrid: Alianza Editorial.

Collier, J. (1957). Photography in Anthropology: A Report on Two Experiments. American Anthropologist, 59(5), 843-859.

Collier, J. y Collier, M. (1986). Visual Anthropology: Photography as a Research Method. Albuquerque: University of New Mexico Press.

Cruces, F. (1998). El ritual de la protesta en las marchas urbanas. En N. García Canclini (Ed.), Cultura y comunicación en la Ciudad de México, segunda parte: la ciudad y los ciudadanos imaginados por los medios (pp. 27-83). México DF: Grijalbo - Universidad Autónoma Metropolitana Iztapalapa.

Cruces, N. (2015, octubre 8). Convocatoria a marcha el 12 de octubre por la resistencia Mapuche. La Izquierda Diario. Recuperado de http:// 
www.laizquierdadiario.cl/Convocatoria-a-marcha-el-12-de-octubre-por-laresistencia-Mapuche

Delgado, M. (2007). Sociedades movedizas. Pasos hacia una antropología de las calles. Barcelona: Anagrama.

Fernández Droguett, F. y Fernández Droguett, R. (2015). El tinku como expresión política: contribuciones hacia una ciudadanía activista en Santiago de Chile. Psicoperspectivas, (14), 62-71.

Fernández, R. (2013). El espacio público en disputa: manifestaciones políticas, ciudad y ciudadanía en el Chile actual. Psicoperspectivas, (12), 28-37.

Fernández, R. (2017). La producción social del espacio público en manifestaciones conmemorativas, Santiago de Chile, 1990-2010. EURE - Revista de Estudios Urbano Regionales, 43(130).

Fernández, R. y Hermansen, P. (2009). Aproximaciones metodológicas para una sociología visual a partir del estudio de prácticas de memoria colectiva en el espacio público de la ciudad de Santiago de Chile. Espacio Abierto, (18), 445-460.

Green, D. (2003). From Presence to the Performative: rethinking photographic indexicality. En D. Green y J. Lowry (Eds.), Where is the photograph? (pp. 4760). Brighton, Maidstone: Photoforum - Photoworks.

Haraway, D. (1995). Ciencia, cyborgs y mujeres. La reinvención de la naturaleza (Trad. M. Talens). Valencia: Ediciones Cátedra - Universitat de Valencia Instituto dela Mujer.

Hermansen, P. (2013). Fotoetnografía: emergencia, uso silencioso y tres irrupciones en la tradición estadounidense (PhD). Pontificia Universidad Católica de Chile, Santiago, RM, Chile.

Hermansen, P. y Chilet, M. (2010). Ciudad Virtual, Ciudad Real: conflicto y emergencia de un nuevo entorno urbano. Diseña, 40-49. 
Hermansen, P. y Fernández, R. (2016). Performatividad y Disputa digitalmente aumentada en el Espacio Público de Santiago de Chile: Fotoetnografia y análisis de la Marcha del Orgullo Gay. International Journal of Marketing, Communication and New Media, Special Number QRMCNM(1), 79-96.

Hernández, R. (2006). Argumentos para una Epistemología del Dato Visual. Cinta Moebio, (26), 196-206.

Ingold, T. (2016). The Sustainability of Everything [Video]. Center for Human Ecology. Recuperado de https://www.youtube.com/watch?v=ncLv9Gk7XrI

Ingold, T. (2017). On human correspondence. Journal of the Royal Anthropological Institute, 23(1), 9-27. doi:10.1111/1467-9655.12541

Jaramillo Marín, J. y Vera Lugo, J. P. (2013). Etnografias desde y sobre el Sur global. Reflexiones introductorias. Universitas Humanística, (75), 13-34.

Latham, A. y McCormack, D. P. (2009). Thinking with images in nonrepresentational cities: vignettes from Berlin. Area, 41(3), 252-262. doi:10.1111/ j.1475-4762.2008.00868.x

Peirce, C. S. (1986). La ciencia de la semiótica. Buenos Aires: Nueva Visión.

Pink, S. (2006). Doing Visual Ethnography. Londres: SAGE Publications.

Rieger, J. (1986). Howard Becker's summer workshop in visual sociology: A personal view. Visual Sociology, 1(1), 5-8. doi:10.1080/14725868608583562

Ruby, J. (1991). Speaking For, Speaking About, Speaking With, or Speaking Alongside - An Anthropological and Documentary Dilemma. Visual Anthropology Review, 7(2), 50-67. doi:doi:10.1525/var.1991.7.2.50

Serres, É. R. A. (1845). Observaciones sobre la aplicación de la fotografia al estudio de las razas humanas. En J. Naranjo (Ed.), Fotografia, antropología y colonialismo (1845-2006) (pp. 26-30). Barcelona: Gustavo Gili.

Sontag, S. (2001). On Photography. New York: Picador. 
Tassin, E. (2013). Les gloires ordinaires. Actualité du concept arendtien d'espace public. Cahiers Sens public, 1 (15-16), 23-36.

Taylor, D. (2016). El archivo y el repertorio: La memoria cultural performática en las Américas. Santiago: Ediciones Universidad Alberto Hurtado.

Voirol, O. (2005). Les luttes pour la visibilité: esquisse d’une problématique. Reseaux, (129-130), 89-121.

Warren, S. (2005). Photography and voice in critical qualitative management research. Accounting, Auditing \& Accountability Journal, 18(6), 861-882.

\section{Cómo citar este artículo}

Hermansen Ulibarri, P. y Fernández Droguett, R. (2018). La foto-etnografia como metodología de investigación para el estudio de manifestaciones conmemorativas contestatarias en el espacio público. Universitas Humanística, 86, 167-196. https://doi.org/10.11144/Javeriana.uh86.fmie 